\title{
Correction to: Aspergillus niger is a superior expression host for the production of bioactive fungal cyclodepsipeptides
}

Simon Boecker ${ }^{1,2}$, Stefan Grätz' , Dennis Kerwat ${ }^{1}$, Lutz Adam¹, David Schirmer ${ }^{1}$, Lennart Richter', Tabea Schütze ${ }^{2}$, Daniel Petras ${ }^{1}$, Roderich D. Süssmuth ${ }^{1 *}$ and Vera Meyer ${ }^{2^{*}}$

\section{Correction to: Fungal Biol Biotechnol (2018) 5:4} https://doi.org/10.1186/s40694-018-0048-3

Following publication of the original article [1], the authors reported that there is a mistake in the legend of
Fig. 4; the explanation of the symbols has been mixed up. The corrected version of Fig. 4 is given below.
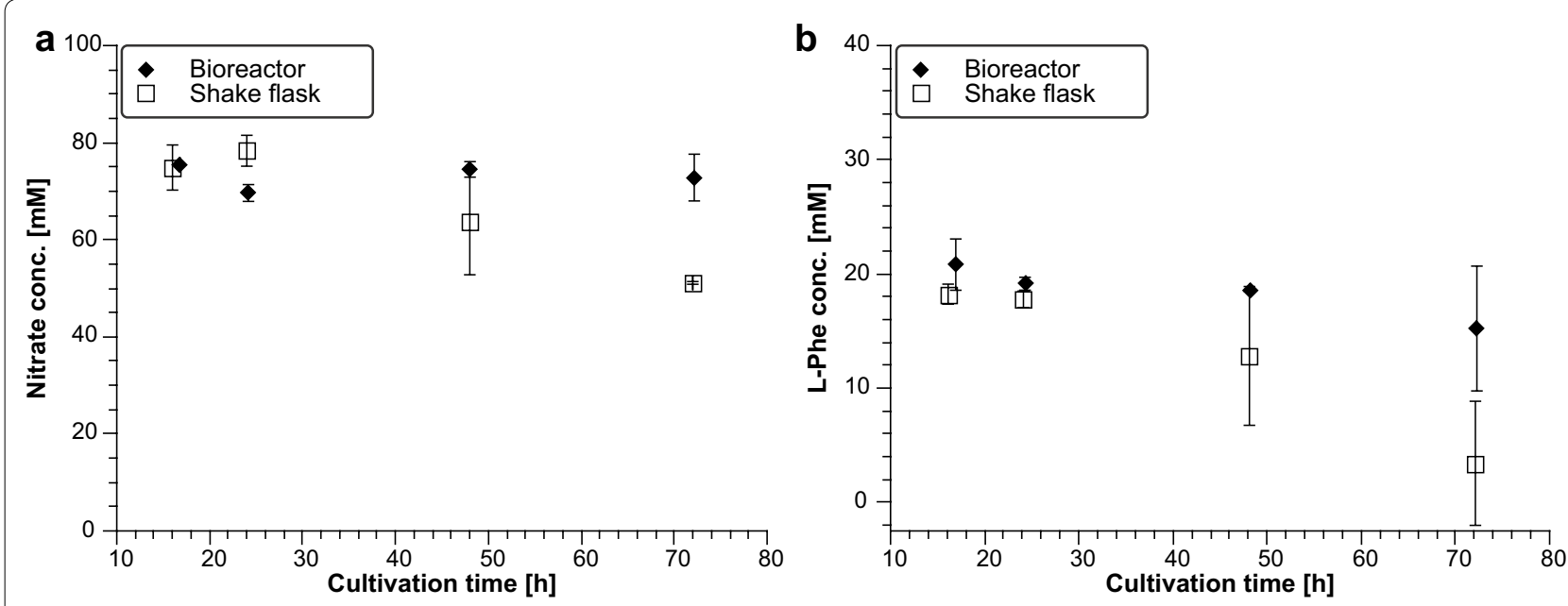

Fig. 4 Nitrate and L-Phe concentrations obtained from shake flask and bioreactor cultivations of strain DSc1.4. a Nitrate concentration in medium of shake flask and bioreactor cultivations; b L-Phe concentration in medium of shake flask and bioreactor cultivations. Measurements for bioreactor runs were done in biological duplicates, for shake flask cultivations in biological triplicates

\footnotetext{
${ }^{*}$ Correspondence: roderich.suessmuth@tu-berlin.de; vera.meyer@tu-berlin.de

1 Department Biological Chemistry, Institute of Chemistry, Technische Universität Berlin, Straße des 17. Juni 124, 10623 Berlin, Germany

2 Department Applied and Molecular Microbiology, Institute

of Biotechnology, Technische Universität Berlin, Gustav-Meyer-Allee 25,

13355 Berlin, Germany
} provided you give appropriate credit to the original author(s) and the source, provide a link to the Creative Commons license, and indicate if changes were made. The Creative Commons Public Domain Dedication waiver (http://creativecommons.org/ publicdomain/zero/1.0/) applies to the data made available in this article, unless otherwise stated. 
The original article can be found online at https://doi.org/10.1186/ s40694-018-0048-3.

\section{Publisher's Note}

Springer Nature remains neutral with regard to jurisdictional claims in published maps and institutional affiliations.

Received: 2 March 2018 Accepted: 12 March 2018

Published online: 27 March 2018

\section{Reference}

1. Boecker et al. Aspergillus niger is a superior expression host for the production of bioactive fungal cyclodepsipeptides. 2018;5:4. https://doi. org/10.1186/s40694-018-0048-3.
Submit your next manuscript to BioMed Central and we will help you at every step:

- We accept pre-submission inquiries

- Our selector tool helps you to find the most relevant journal

- We provide round the clock customer support

- Convenient online submission

- Thorough peer review

- Inclusion in PubMed and all major indexing services

- Maximum visibility for your research

Submit your manuscript at www.biomedcentral.com/submit 